\title{
Report
}

\section{Evaluation of heavy metal pollution in the Ergene River Basin from a public health perspective}

\author{
Ayşe Handan Dokmecia \\ a School of Health, Emergency and Disaster Management Dept., Namik Kemal Univ., Tekirdağ, TURKEY
}

Submitted date: 14.03.2016, Accepted date: 05.03.2017

\begin{abstract}
Objective: The aim of this report is to evaluate the heavy metal pollution of the Ergene Basin and its effects on public health. Methods: Local people, as well as the surrounding ecosystem, are exposed to varying levels of chemical substances. Those working in different industrial sectors are particularly vulnerable. Ergene river, one of the most important water sources in the Thrace region, is being rapidly polluted due to increasing industrialization and urbanization in the region. Many chemicals are discharged into the Ergene river without proper treatment. This is largely due to the inadequacy of residential and industrial treatment plants, as well as the proliferation of illegal dumping in the region. Thus, both the environment and the people face a serious threat. For many years there have been many studies investigating the presence and effects of heavy metals on the water, soil, air, plants, animals and people of the region. In our study, the literature on heavy metal concentrations in the region was summarized and the five-year cancer statistics were evaluated. Results: The lead concentration, which is a common metal in all the different environmental compartments, has been found to be above the maximum limit value. Furthermore, the evaluation of cancer data showed an increase in all cancer types between 2006 and 2011. Conclusion: Although it is difficult to relate cancer and environmental factors directly, studies show that there may be a close relationship between lead concentration (largely produced by the textile and leather industries) and the occurrence of bladder and kidney cancers. However further research, such as risk assessments, is required to establish more definitive conclusions.
\end{abstract}

Key words: Toxic metals, Ergene river basin, cancer rates, public health, river pollution

Corresponding Author: Ayșe Handan Dokmeci, School of Health, Emergency and Disaster Management Department, Namik Kemal University, 59030, Tekirdağ, TURKEY e-mail: hdokmeci@nku.edu.tr

Copyright holder Turkish Journal of Public Health

This work is licensed under a Creative Commons Attribution-NonCommercial 4.0 International License. (cc) EY-No This is an open Access article which can be used if cited properly. 


\title{
Ergene Nehri Havzasında ağır metal kirliliğinin halk sağlığı açısından değerlendirilmesi
}

\begin{abstract}
Özet
Amaç: Bu raporun amacı Ergene Havzasında ağır metal kirliliğinin halk sağlığına olan etkilerini değerlendirmektir. Yöntem: Değişik endüstri kollarında çalışanlar bașta olmak üzere, tüm insanlar ve diğer canlılar az ya da çok kimyasal maddelere maruz kalmaktadırlar. Trakya bölgesindeki önemli su kaynaklarından biri olan Ergene nehri de, civarında yoğun endüstrileşme ve kentleșmeden dolayı hızla kirlenmektedir. Bölgede evsel ve endüstriyel arıtma tesislerinin yetersizliği ve kaçak deşarjlar nedeniyle uygun arıtma yapılmadan birçok kimyasal madde Ergene nehrine deşarj edilmektedir. Dolayısıyla hem çevre hem de insanlar ciddi tehdit altındadır. Uzun yıllardır bölgede suda, toprakta, havada, bitkilerde, hayvanlarda ve insanlarda ağır metaller ile ilgili pek çok çalışma yapılmıştır. Çalışmamızda bölgede yapılmış ağır metal konsantrasyonları ile ilgili literatür özetlenerek, beş ylllı kanser istatistiklerinin değerlendirilmesi yapılmıştır. Bulgular: Farklı çevresel materyaller de yapılmış çalışmalara bakıldığında hepsinde ortak metal olan kurşun konsantrasyonu sınır değerlerin üzerinde tespit edilmiştir. 2006-2011 yılları arasında kanser verilerinin değerlendirilmesi sonucu da tüm kanser tiplerinde artış görülmüştür. Sonuç: Kanser ve çevresel faktörleri bire bir ilişkilendirmek zor olsa da, yapılan çalışmalar ve kanser istatistikleri, kurşun konsantrasyonları - tekstil ve deri sektörü - mesane ve böbrek kanserleri arasında yakın ilişki olabileceğini göstermektedir. Ancak risk değerlendirmesi gibi daha ileri çalışmalara ihtiyaç duyulmaktadır.
\end{abstract}

Anahtar kelimeler: Toksik metaller, Ergene Nehri Havzası, kanser oranları, halk sağlığı, nehir kirliliği

\section{Introduction}

Heavy metals are one of the most important contributors to inorganic pollution. Although certain heavy metals are essential for living organisms, heavy metals also have the potential to accumulate in living tissues and cause toxic effects above certain concentrations. Despite the fact that most heavy metals are naturally found in ecosystems, toxic levels of these metals are often released into the environment within the context of industrial and agricultural activities. The association between exposure to heavy metals, either occupational or environmental, and cancer has been extensively studied.1,2 The uncontrolled and continuous release of these metals into the industrialization and the use of various synthetic chemicals in our daily lives. Thus, environmental pollution is now considered one of the causative factors of cancer, along environment (i.e. surface and ground waters, the atmosphere, the soil) can lead to serious health problems among humans. These heavy metals can reach humans through the food chain, and cause both acute and chronic effects following their entry into the body.

Besides the general toxicities of metals, we are today also concerned with the potential carcinogenicity of metal compounds. Certain metals such as chromium and nickel have been linked with cancers in exposed human populations. ${ }^{3,4}$ Although environmental pollution cannot be described as a direct trigger of cancers among humans, the rapid increase in cancer rates observed over the past decades suggests a strong correlation with

with other factors such as nutrition, smoking, and genetics. ${ }^{5-9}$ Our study includes a brief evaluation of some studies on heavy metals 
in the Ergene Basin over the last 20 years and the assessment of the results in public health.

\section{Material and Method}

Turkish Thrace includes the cities Edirne, Tekirdag, Kırklareli and some parts of Istanbul and Canakkale provinces. Edirne and Tekirdag are the most important provinces in Meric-Ergene River Basin in Turkish Thrace. Industrial and agricultural activities related to water, and animal husbandry for livestock and poultry are very common in this area ${ }^{10,11}$. The most important source of surface water in the Ergene Basin is the Ergene River and its branches. The mouth of the Ergene River, which passes through the center of the Basin, has sources in the environs of the Taşpınar Hill, within the Saray County of Tekirdağ Province. From these sources, the Ergene River flows southwards, at first as a stream, and then as a river after merging with the Çorlu Stream flowing from Çerkezköy County ${ }^{12}$ (Fig 1).

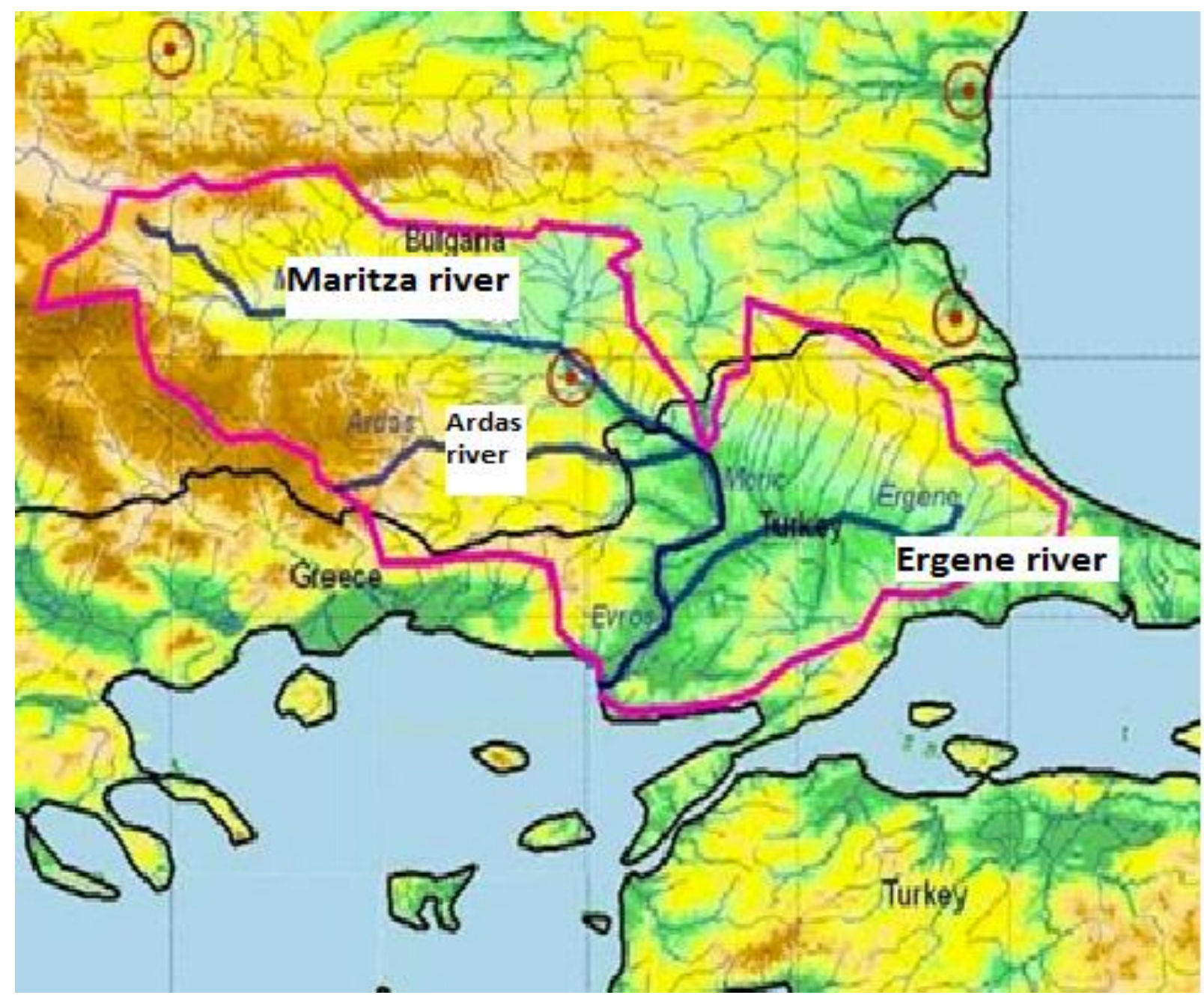

Figure 1. Ergene-Evros-Ardas River Basin

As a result of industrialization, the Tekirdağ Province is constantly receiving immigrants from other provinces, and the ecosystem of the region is becoming increasingly polluted. Both the treated and untreated waste waters of industries in Çorlu 
and its environs are flowing into the Çorlu Stream, creating a significant environmental hazard for the region. Several studies in this region have demonstrated high concentrations of heavy metals in its water, sediment, soil, air, plants, and animals, and even among its human inhabitants. ${ }^{13-16} \mathrm{We}$ report, moreover, the review of relevant literature.

\section{Results and Discussion}

\section{Heavy Metal Pollution at Ergene River Basin}

The Ergene River is one of the most important sources of water in its region. However, the river is becoming increasingly polluted due to the presence of many industries, and especially of textile factories, in its environs. The Ergene River is increasingly becoming a health hazard for the both the people and organisms that live in its environs. The threats associated with the Ergene Rivers include: the flooding of the rivers, which carries pollutants to agricultural lands; the insufficiency of facilities for the treatment of domestic and industrial waste water in the region; the leakage of pollutants into the ground water; and the flow of pollutants through the Ergene River towards the Northern Aegean Sea, especially after meeting the Meriç River.

Heavy metal pollution in surface water, groundwater, sediment, soil and plant samples;

A study involving the analysis of rice and surface water samples was performed in 2001 in the environs of the Ergene River. The results of this study demonstrated $\mathrm{Mn}$ and $\mathrm{Fe}$ concentrations above the limit values and at phytotoxic levels in all parts of the rice plant samples; and $\mathrm{Zn}, \mathrm{Pb}$ and $\mathrm{Ni}$ concentrations above the limit values and at phytotoxic levels within the roots of rice plants. ${ }^{17}$ In another study performed at Çorlu between 2006 and 2008, $\mathrm{Pb}$ and $\mathrm{Cu}$ concentrations above normal limit values and at phytotoxic levels were identified in plant samples, while certain samples (those from the Türkgücü village area) also showed $\mathrm{Ni}$ and $\mathrm{Cd}$ concentrations above limit values. ${ }^{18}$ A study performed in 2005 in areas surrounding the Çorlu-Çerkezköy road identified $\mathrm{Pb}$ concentrations significantly above limit values in soils used for agriculture. Within the context of the said study, the order with respect to concentration of the heavy metals identified in the soil was $\mathrm{Fe}>\mathrm{Mn}>\mathrm{Pb}>\mathrm{Cr}>\mathrm{Zn}>\mathrm{Ni}>\mathrm{Cu}>\mathrm{Cd}$, while the order with respect to concentration of the heavy metals identified in wheat plant samples was $\mathrm{Fe}>\mathrm{Mn}>\mathrm{Zn}>\mathrm{Ni}>\mathrm{Pb} .{ }^{19}$ Furthermore, in a study conducted in various industrialized areas of Çorlu County between 2006 and 2008, soil samples collected at certain time intervals demonstrated high concentrations for certain heavy metals. Although the periodically collected soil samples showed $\mathrm{Pb}$ levels below limit values in the evaluated areas, the concentrations of the other heavy metals were, depending on the sampled region, frequently above the limit values. All these study findings indicate that although heavy metals were not considered a source of problems or a hazard in the Çorlu region in the 2000s, these heavy metals' ability to accumulate in soils and sediments, as well as their ability to reach ground water through to the action of rainwater, presents a very significant risk of heavy metal-related environmental problems for the region's near future. ${ }^{18,20} \mathrm{~A}$ study performed in 2010 further confirmed this risk by demonstrating above limit $\mathrm{Pb}$ concentrations in soil samples collected from Çorlu, Şarköy, Ereğli, and Tekirdağ's Provincial Capital. ${ }^{21}$

Our previous study conducted between 2006-2008, groundwater samples showed above limit $\mathrm{Ni}$ concentrations depending on the time and location in which the samples were obtained. Another important observation of this study was that although the concentrations of other heavy metals in the sampled locations were below limit values at the time of the study period, these concentrations, nevertheless, demonstrated a gradual and uninterrupted increase. ${ }^{22}$ Heavy metal analyses performed between 2006 and 2010 by the XIth Regional Directorate of the State Hydraulic Works at 
six wells located on the Çorlu-Çerkezköy aquifer system demonstrated that according to the criteria of the Water Pollution Control Regulation (WPCR), the aquifer's waters were of "First Class" quality with respect to $\mathrm{Mn}, \mathrm{Cu}, \mathrm{Zn}$, and $\mathrm{Fe}$ concentrations. However, samples collected by the same Directorate from Çerkezköy in 2010 showed $\mathrm{Pb}$ concentrations considerably above limit values.

As the water sources and wells associated with the aquifer system are used for drinking water, it is necessary to conduct studies to increase and ensure the quality and safety of these waters. ${ }^{23}$ In another study, $\mathrm{Fe}, \mathrm{Zn}, \mathrm{Mn}, \mathrm{Cr}, \mathrm{Cd}$, and $\mathrm{Pb}$ concentrations were analyzed in groundwater samples obtained from 17 different wells in the Corlu region. These analyses were performed on a monthly basis, and continued for a period of one year. The results of this study demonstrated that groundwater in the Çorlu-Vakıflar area had yearly average $\mathrm{Cr}, \mathrm{Cd}$, and $\mathrm{Pb}$ concentrations of $0.65 \mathrm{mg} / \mathrm{l}, \quad 0.04 \mathrm{mg} / \mathrm{l}$ and $0.23 \mathrm{mg} / \mathrm{l}$, respectively, which are considerably above the limit values defined by the Turkish Standards Institution (Türk Standartlar Enstitüsü, TSE), the Environmental Protection Agency (EPA), and the World Health Organization (WHO). ${ }^{24}$ In another research conducted in 2013 was to investigate the concentrations of the heavy metals (copper, iron, zinc, chromium, cadmium and lead) and determine their relationship between $\mathrm{pH}$ and $\mathrm{EC}$ in the east of Ergene Basin, Turkey. Results show that mean concentrations of $\mathrm{Cu}, \mathrm{Fe}, \mathrm{Zn}, \mathrm{Cr}, \mathrm{Cd}$ and Pb were, 0.005, 0.012, 0.083, 0.016, n.d. and $0.0006 \mathrm{mg} \mathrm{L}^{-1}$ respectively, with the decreasing sequence of $\mathrm{Zn}>\mathrm{Cr}>\mathrm{Fe}>\mathrm{Cu}$ $>\mathrm{Pb}>\mathrm{Cd}$. No significant correlations were found among metals. Only moderate positive correlation was determined between $\mathrm{Pb}$ and $\mathrm{pH}(\mathrm{r}=0.451 ; \mathrm{p}<0.05)$. All metal pollutants studied in the groundwater were below international and national guidelines except Cr. ${ }^{25}$

In a study conducted at Çorlu between 2006 and 2008, it was observed that the quality of surface water varied depending on the locations and months in which the samples were obtained.When evaluated according to the WPCR criteria, it was determined that the surface waters were of "Third and Fourth Class" quality with respect to $\mathrm{Cu}, \mathrm{Fe}, \mathrm{Zn} \mathrm{Cd}, \mathrm{Ni}$, and $\mathrm{Pb}$ concentrations. ${ }^{26}$ Analyses performed by the Edirne Provincial Directorate of the Environment and Forestry between 2009 and 2010 in the environs of the Akarca Bridge of the Ergene River (located at the very boundary of the Tekirdağ Province) demonstrated that the River was of "Fourth Class" quality (in other words, "Very Polluted") with respect to physical and inorganic/chemical parameters; of "Fourth Class" quality with respect to organic parameters; and of "Fourth Class" quality with respect to inorganic parameters. ${ }^{27}$

In 2011, Sunguret.al (2014) reported, the risk assessment code indicated that the highly mobile soluble fractions of $\mathrm{Mn}, \mathrm{Zn}, \mathrm{Cd}$ and Co created a high environmental risk which could result in negative impacts in the sediments of the Ergene River, Turkey.28 According to Hallı et.al (2014), the results of enrichment factor (EF), contamination factor (CF), and pollution load index (PLI) reveal that the sediments of the Ergene River were not polluted with $\mathrm{Cu}, \mathrm{Fe}, \mathrm{Mn}$, and $\mathrm{Ni}$, but were moderately polluted with $\mathrm{As}, \mathrm{Cr}, \mathrm{Pb}, \mathrm{V}$, and $\mathrm{Zn}$. The highest CF and PLI of As, Cr, and V were observed near the industrial district of Çorlu. These CF and PLI values indicated anthropogenic influence caused by the input of untreated industrial wastewater and domestic sewage. ${ }^{29}$ In order to investigate the pollution level of selected toxic metals in the river, 20 surface sediment samples were collected and analyzed. Results indicated that the investigated samples were moderately contaminated with $\mathrm{Ag}, \mathrm{Cr}$ and $\mathrm{As}$, moderately to severely contaminated with $\mathrm{Zn}$ and $\mathrm{Ni}$, and severely contaminated with $\mathrm{Cu}^{30}$

Our previous study conducted between 2011-2012, a study on marine pollution in the region identified $\mathrm{Pb}, \mathrm{As}$, and $\mathrm{Cu}$ levels above those permitted by the Turkish Food Codex in shrimp sample collected from the coasts of Tekirdağ31.In addition, another research is to determine the mercury, lead and cadmium accumulation in scads (Trachurustrachurus) caught in the near Tekirdag in the sea of 
Marmara in 1996. Fish sample average mercury contents were 0.029 ppm and average lead contents were 0.038 respectively. This levels below those permitted by the Turkish Food Codex in fish sample collected from the coasts of Tekirdağ. ${ }^{32}$

\section{Heavy metals and the link to cancer}

The World Health Organization (WHO) has reported that $80 \%$ of all cancers are directly or indirectly due to environmental factors. In addition, WHO's report, "Prevention of Diseases Through Healthy Environment" states that about $19 \%$ of undesirable environmental factors play a role in the world wide cancer and that 1.3 million people die per year. ${ }^{33}$

In a study on human health conducted around the Ergene River region, heavy metal levels were evaluated in samples obtained from the nails of cases with renal, urothelial, and prostate tumors. The study results demonstrated high Cd levels among all cases with one of the mentioned tumors, and high $\mathrm{Cu}, \mathrm{Zn}$, and $\mathrm{Pb}$ levels among cases with renal and urothelial tumors. ${ }^{34}$ In another study, the levels of certain heavy metals were evaluated in the blood, tumor tissues, and normal tissues of cases with renal tumors. The results of this study showed significantly high levels of $\mathrm{Pb}$ and $\mathrm{Cd}$ in the tumorous and normal tissues (as well as the renal tissues) of individuals with renal tumors living near the Ergene River. ${ }^{35}$

In another similar study, researchers analyzed $\mathrm{Pb}, \mathrm{Cd}, \mathrm{Fe}, \mathrm{Cu}$ and $\mathrm{Zn}$ concentrations, which are intensely detected in Ergene river, in serum, tumorous and normal tissues of cases with bladder tumor in Thrace. Cd in the serum of all cases has been found significantly higher compared reference values and no difference was observed between groups. $\mathrm{Pb}$ levels rise significantly when tumor stage also rises. In tumor tissues in all cases, $\mathrm{Pb}$ and $\mathrm{Cd}$ levels were detected to be higher compared to reference values, whereas $\mathrm{Pb}$ levels in normal tissue were also significantly higher.
Cd levels were significantly higher in normal and tumorous tissue in invasive tumors compared to superficial tumors. In normal tissue comparison of Ergene group, Fe level was found significantly low, whereas $\mathrm{Zn}, \mathrm{Cd}$ and $\mathrm{Pb}$ levels were significantly high. ${ }^{36}$

In a study supporting other studies carried out in the Corlu region revealed an increase in the number of cancers in the settlements near Ergene Stream, Marmaracik Stream and Çorlu Stream, contaminated with industrial wastewaters in Tekirdag province. Significant relationships have been found between the distances of the places where the residents of the study are residing and the distances of the industrial wastes to the water sources from which they are discharged. ${ }^{37}$

In the Dilovası Report published by the Turkish Medical Association in 2012, It has been emphasized that the risk of dying from cancer in industry-intensive regions is 4.4 times higher than those living in less than 10 years, in those living in Dilovasi, which is 10 years or longer. ${ }^{38}$ Cancer data collected by the Tekirdağ Provincial Directorate of Health between 2006 and 2011 is shown in Figure 2. In this figure, the increase observed in the incidenceany type of cancer in 5 years can be considered to be a confirmation of the abovementioned findings regarding the health hazards presented by heavy metal pollution in the Ergene River region. Studies that have been conducted over the past years clearly demonstrated the effects of heavy metal pollution in the waters, the sediment, the soil and the plants and animals of the region. Especially $\mathrm{Pb}$, which is considered by the International Agency for Research on Cancer (IARC) as a potential human carcinogen, was detected above the limit values at the environs of the Ergene River. All these observations strongly suggest a relationship between environment pollution and the incidence of cancer. United States Environmental Protection Agency (U.S. EPA) has determined that lead is a probable human carcinogen too (Table 1). Lead can affect every organ and system in the body. Long-term exposure of adults can result in 
decreased performance in some tests that measure functions of the nervous system; weakness in fingers, wrists, or ankles; small increases in blood pressure; and anemia. Exposure to high lead levels can severely damage the brain and kidneys and ultimately cause death. The link between lead exposure and cancer is clearly a concern, and more research is needed to better define the possible link between lead exposure and a number of cancers. $4,39,40$ The records on cancer of the Ministry of Health indicate that the increase in cancer incidence within the
Thracian region is somewhat different from the increase observed in other parts of Turkey. The authors believe that the present study will contribute significantly to bringing together many other studies on the subject, to increasing the knowledge and awareness of local administrations regarding the pollution in the Ergene River region, and to identify multidisciplinary solutions for these environmental problems.

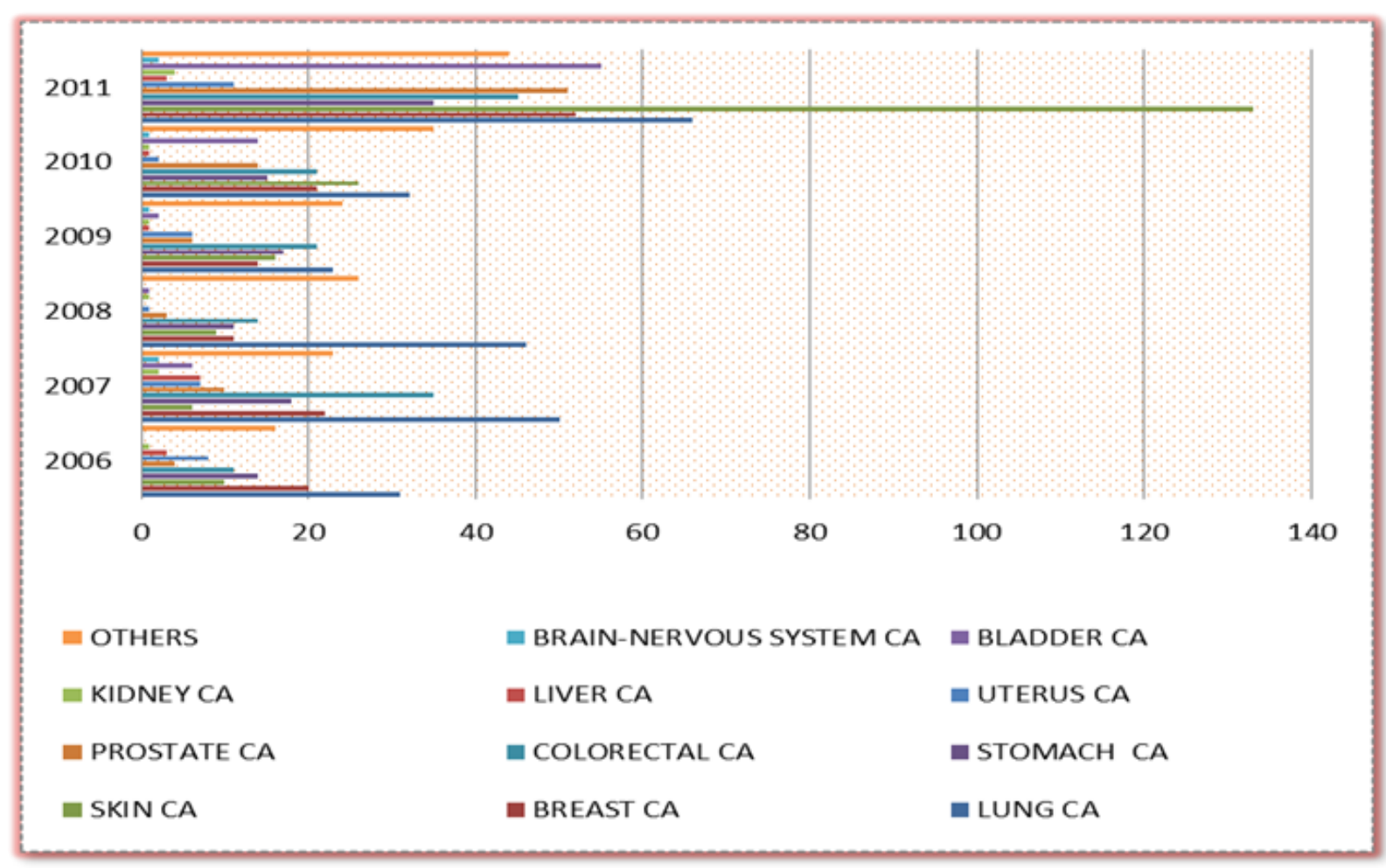

Figure 2. Estimates of cancerincidence in Tekirdağ, Turkey, 2006-2011 
Table 1. Presence of Heavy Metals in environmental compartments and biological material of living persons around the Ergene River Basin

\begin{tabular}{|c|c|c|c|c|c|c|c|c|c|}
\hline Samples & $\mathrm{Pb}$ & $\mathrm{Ni}$ & $\mathrm{Cr}$ & $\mathrm{Cd}$ & As & $\mathrm{Cu}$ & $\mathrm{Zn}$ & $\mathrm{Mn}$ & $\mathrm{Fe}$ \\
\hline Plant & $*$ & $*$ & & $*$ & & $*$ & $*$ & $*$ & \\
\hline Soil & $*$ & & & & & & & $*$ & \\
\hline Sediment & $*$ & & $*$ & $*$ & $*$ & & & $*$ & \\
\hline Ground water & $*$ & $*$ & $*$ & $*$ & & & & & \\
\hline Surface water & $*$ & $*$ & & & & $*$ & $*$ & & $*$ \\
\hline Sea food & $*$ & & & & & & & & \\
\hline Blood samples & & & & & & & & & $*$ \\
\hline Kidney tissue & $*$ & & & $*$ & & $*$ & & & \\
\hline Renal tumor & $*$ & & & $*$ & & $*$ & $*$ & & \\
\hline Urothelial tumors & $*$ & & & $*$ & & $*$ & $*$ & & \\
\hline $\begin{array}{l}\text { Nails of the patients with } \\
\text { urothelial tumor }\end{array}$ & $*$ & & & $*$ & & $*$ & $*$ & & \\
\hline
\end{tabular}

Ethical issues

Ethical Committee approval is not obtained since any data related to human subjects or living organisms are not provided in this report and there is no conflict of interest.

\section{Conflict of interest}

There is no financial support

\section{References}

1-Balkwill F, Mantovani A. Inflammation and cancer: back to Virchow? Lancet 2001;357:539-45.

2-Waisberg M, Joseph P, Hale B, Beyersmann D. Molecular and cellular mechanisms of cadmium carcinogenesis. Toxicology 2003;192:95-117.
3-Sáa I, Semedob M, Cunhac M.E. Kidney cancer. Heavy metals as a risk factor. Porto Biomed J 2016;1(1):25-28.

4- Mahurpawar. M Effects Of Heavy Metals On Human Health. International Journal of Research-GRANTHAALAYAH.2015; http://granthaalayah.com/Articles/Vol3Iss 9SE/152_IJRG15_S09_152.pdf.

5-Hemdan N.Y, Emmrich F, Faber S, Lehmann J, Sack U. Alterations of TH1/TH2 reactivity by heavy metals: possible consequences include induction of autoimmune diseases. Ann N Y Acad Sci 2007;1109:129137.

6-Antwi S.O, Eckert E.C, Sabaque C.V, Leof E.R, Hawthorne K.M, Bamlet W.R, Chaffee K.G, Oberg A.L, Petersen G.M. Exposure to environmental chemicals and heavy metals, and risk of pancreatic cancer. Cancer Causes Control 2015;26(11):1583-1591. 
7-Chen C.Y, Peng C.H, Chen Y.Y, Chan C.C, Yu C.J. Association of environmental heavy metals exposure and lung cancer incidence and prognosis. European Respiratory Journal 2016; 48: P2805.

8- Caffo M, Caruso G, Fata G.L, Barresi V, Visalli M, Venza M and Venza I. Heavy Metals and Epigenetic Alterations in Brain Tumors. Curr Genomics 2014;15(6):457-463.

9- Tchounwou PB, Yedjou CG, Patlolla AK, Sutton DJ. Heavy Metals Toxicity and the Environment 2012;101:133-164.

10-Ozkahya P, Camur Elipek B. Nutrient contents and physicochemical properties of well waters in Meric (Maritsa) river basin at Turkish Thrace. Bulgarian Chemical Communications, 2016;48(1):21-26

11-Sivri N. Estimation of nutrient loads in ergene basin through GIS. Fresenius Environmental Bulletin 2014;23(12a):32123221

12- Güneş EH, Talinli I. Deşarj-bağımlı ve deşarj-aşırlıklı sistemlerde zehirlilik ile kirletici parametreler arasındaki ilişki. ITU J Ser E Water Pollut Control 2009;19(12):53-62.

13-Sakcali M.S, Yilmaz R, Gucel S, Yarci C, Ozturk M. Water pollution studies in the rivers of the Edirne Region-Turkey. Aquat Ecosyst Health Manage 2009;12(3):313319.

14-Oezkan N, Moubayed-Breil J, CamurElipek B. Ecological analysis of chironomid Larvae (Diptera, Chironomidae) in Ergene River Basin (Turkish Thrace). Turk J Fish Aquat Sci 2010;10(1):93-99.

15-Günes, E, Talınlı I.A site-specific index to control the total effect of point sources discharges and to achieve 'good chemical status' in effluent dependent and effluent dominated water bodies: application on Ergene River Basin. Water Resour Manage 2013;27(1):221-237.

16-Filiz Ü.V. Edirne Yöresinde Yetiştirilen Çeltik Bitkisinin Bazı Ağır Metal İçeriklerinin Belirlenmesi (tez). Tekirdağ: Namık Kemal Üniversitesi Fen Bilimleri Enstitüsü; 2011.

17-Tok H.H, Adiloğlu A, Öner N, Gönülsüz E, Adiloğlu S. Heavy metal concentrations in irrigation waters and rice culture in the central Trakya region. Journal of Environmental Protection and Ecology 2005;6(3):550-562.

18-Sabudak, T, Kaykıglu, G, Ongen, A, Dokmeci AH, Celik, Dokmeci, I. Determination of Nickel and Lead Contents in Soil and Plant in Corlu-Turkey". Environmental Protection and Ecology 2008;9(3).557-565.

19- Ekmekyapar F, Şabudak T, Şeren G. Assessment of Heavy Metal Contamination in Soil and Wheat (Triticumaestivum L.) Plant Around the Çorlu-Çerkezköy Highway in Thrace Region. GlobalNEST 2012;14:496504.

20- Bayrak Yılmaz, G. and Sivri, N., 2014, "Estimation of Nutrient Loads in Ergene Basin throught GIS", Fresenius Enviromental Bulletion, 2014;23(12a):3202-3211.

21- Adiloğlu A, Adiloğlu S, Bellitürk K et.al. Tekirdağ ili kıyı şeridi topraklarında ağır metal kirliliği. 1. Kıyı Bölgelerinde Çevre Kirliliği ve Kontrolu Sempozyumu; 2011; Tekirdag, Turkey; 351-365.

22-Ongen A, Dokmeci AH, Celik S, Sabudak T, Kaykioglu G, Dokmeci I. Copper and Cadmium and Ground and Surface Water in Corlu-Turkey", Environmental Protection and Ecology 2008;9(4):754-763.

23-Ekmekyapar F, Karabulut A, Pagano, SM. Çorlu- Çerkezköy Çevresinde Yeraltı Suyu Seviyelerinin ve $\mathrm{Su}$ Kalitesinin Değerlendirilmesi. 1. Kıyı Bölgelerinde Çevre kirliliği ve Kontrolü Sempozyumu Bildiriler Kitabı 2011;703-711.

24-Arkoç 0. Ergene Havzası, ÇorluÇerkezköy Kesiminde Yeraltı sularındaki Ağır Metal Kirliliğinin Araştırılması. 65.Türkiye Jeoloji Kurultayı; 2012 Nisan 2-6; Ankara, Türkiye.

25-Anonim. Çorlu Bölgesindeki, Çevre Bileșenlerinde İz Element ve Ağır Metal İçeriğinin Grafit Fırınlı Atomik Absorpsiyon Spektrometresi İle Belirlenmesi (20052008). Trakya University Research Project TUBAP-720, Edirne, Türkiye, 2010.

26- T.C. Edirne Valiliği İl Çevre ve Orman Müdürlüğü. Ergene Analiz Raporu. 2009 ve 2010, Edirne, Türkiye, 2010. 
27-Arkoc 0. Heavy Metal Concentrations of Groundwater in the East of Ergene Basin, Turkey. Bulletin of Environmental Contamination and Toxicology 2014;93(4):429-433.

28-Sungur A, Soylak M, Yilmaz S, Özcan H. Determination of heavy metals in sediments of the Ergene River by BCR sequential extraction method. Environ Earth Sci 2014;72:3293-3305.

29-Hallı M, Sarı E, Kurt M.A. Assessment of Arsenic and Heavy Metal Pollution in Surface Sediments of the Ergene River, Turkey. Pol J Environ Stud 2014;23(5):1581-1590.

30- Erol S, Cukrov N, Franc is `kovic B.S, Kurt M.A, Halli M. Contamination assessment of ecotoxicmetals in recent sediments from the Ergene River, Turkey. Environ Earth Sci 2016; 75:1051.

31-Dokmeci A.H, Yildiz T, Ongen A, Sivri N. Heavy metal concentration in deepwater rose shrimp species (Parapenaeuslongirostris, Lucas, 1846) collected from the Marmara Sea Coast in Tekirdağ. Environ Monit Assess 2014;186:2449-2454.

32-Demirkol 0, Aktaş N. A Search On Heavy Metal Accumulation In Scads Caught In The Gulf Of İzmit and off Tekirdag Province In The Sea Of Marmara. Pamukkale Univ Muh Bilim Derg 2002;8(2):205-209

33-World Health Organization (WHO). Preventing disease through heal thy environments.http://www.who.int/quantif ying_himpacts/publications/preventingdise ase.pdf. Available at 17.09.2016.

34-Inci O, Gülyaşar T, Yolal M, Cakina S, Sut N. Endüstriyel atıklarla ağır derecede kirlenen Ergene Nehri çevresinde yaşayan Ürogenital tümörlü olguların tırnaklarında bazı ağır metallerin araştırılması. 11. Üroonkoloji Kongresi. Bildiri özetleri kitabı. 2013a; 467-468.

35-Inci, O, Yolal M, Gülyaşar T, et.al. Ergene nehri çevresinde ve diğer yerleşimlerde yaşayan böbrek tümörlü olguların kan ve böbreğin normal ve tümörlü dokularında bazı ağır metallerin araştırılması, nehir kirliliği ile ilişskisinin değerlendirilmesi. 11. Üroonkoloji Kongresi. Bildiri özetleri kitabı 2013b;57-58.

36- Yolal M. Investigation of Relationship With Heavy Metals and River Pollution at Tumor Tissue and Normal Epithelial, Blood Serum of Patients With Urogenital Tumor that Live Near Ergene Riverand TurkishTrace. Trakya University. Uzmanlık Tezi. Edirne-2014.

37- Yorulmaz F, Berberoğlu U, Sayhan ES, Eskiocak M, Gamze K. Endüstri yoğun bölgede yaşayanlarda ya da birinci derecede yakınlarında kanser bildirenlerin çevresel risk etmenlerine göre değerlendirilmesi: Çorlu örneği. 15. Ulusal Halk Sağlığı Kongresi Özet Kitabı, Bursa, 2012:730.

38- Türk Tabipleri Birliği Dilovası Raporu. Ankara: Türk Tabipleri Birliği Yayınları, 2012.

39- Martin S, Griswold W. Human Health Effects of Heavy Metals. Center for Hazardous Substance Research. 2009;15.

40-ATSDR (Agency for Toxic Substances and Disease Registry). Toxic substances Portal. https://www.atsdr.cdc.gov/substances/tox substance.asp?toxid $=22$ Available at: 23.12.2016. 